\title{
Sokol Hareketi: Nasyonalist ve Politik Bir Araç Olarak Jimnastiğin Kullanımı
}

\author{
Aylin UĞURLU 1 (D), Tolga ŞiNOFOROĞLU 2 \\ ${ }^{1}$ Gazi Üniversitesi Sağlık Bilimleri Enstitüsü, ANKARA \\ ${ }^{2}$ Kütahya Dumlupınar Üniversitesi Spor Bilimleri Fakültesi, KÜTAHYA
}

Araştırma Makalesi

DOI:10.53434/gbesbd. 984507

Öz

Bu çalışmanın amacı Sokol hareketinin ortaya çıkışı, diğer ülkelerdeki yansımaları ve milliyetçilik düşüncesi üzerinden siyasi etkilerinin değerlendirilmesidir. Sokol Hareketi tarihinin Prag Jimnastik Kulübü'nün 1862'de Miroslav Tyrš tarafından kurulmasıyla başladığı kabul edilmektedir. Tyrš, Sokol Hareketi ile halkını jimnastiğe teşvik ederek tüm Slav halklarını kültürel ve ulusal bakımdan iyileştirmeyi amaçlamıştır. Sokol Hareketi'nin görevi ise üyelerini ahlakl, etik ve estetik açıdan, demokrasi prensiplerine uyumlu biçimde beden eğitimi vasitasıyla ulusal bütünlük yolunda eğitmek olarak tanımlanmıştır. Alman ve İsveç jimnastiklerini kendi milli ihtiyaçlarına göre harmanlayan Tyrš, kısa sürede tüm Slav halkları üzerinde iz bırakmış ve Sokol 20. yüzyıl başlarından itibaren başta Orta, Doğu ve Güney Avrupa olmak üzere tüm dünyaya yayılmıştır. Özgürlük ve demokrasi arzusu ile ezilen ulusların yabancı esaretinden kurtuluşunun en güçlü temsilcilerinden olan Sokol, başlangıçtan itibaren Slav ulusal bilincinin ve milliyetçiliğinin oluşmasında önemli rol oynamışve diğer halklara da örnek olmuştur. Gerek Slav yurdu dışında yaşayan Slavların örgütlenmeleri gerekse farklı toplumların Sokol benzeri örgütlenme çalışmaları, beden eğitimi ve spor yoluyla yurt savunmasının ve halkı güçlendirmenin en önemli araçları olmuşlardır. Sokol'un 50 yıldan kısa sürede ulaştığı devasa güç her dönem siyasilerin ilgisini çekmiş, yönetim şekilleri değişse de Sokol Hareketi hükümetlerin sosyal politikalarının önemli bir parçasını oluşturmuştur. Benzer biçimde Sokol'un güçlü ve sistematik yapısı ülke düşmanları tarafından bir tehdit olarak algılanmış ve işgal dönemlerinde Sokol Hareketi pasivize edilmeye çalışılmıştır. Ancak farklı dönemlerde kesintiye uğrasa da Sokol Hareketi, özellikle Sokol Festivalleri yoluyla her dönem halkla bütünleşmeyi sağlamış ve günümüze kadar varlığını sürdürmeyi başarmıştır. Sokol günümüzde halen Çek milliyetçiliğinin en önemli yapı taşlarından birini oluştururken, ulusal bilincin ve demokrasinin de en güçlü savunucusu olmaya devam etmektedir.

Anahtar sözcükler: Sokol, Çek Cumhuriyeti, Miroslav Tyrš, Beden eğitimi ve spor, Milliyetçilik 


\title{
Sokol Movement: Use of Gymnastics as a Nationalist and Political Tool
}

\begin{abstract}
The aim of this study is to evaluate the emergence of the Sokol Movement, its reflections on other countries and political impact on nationalist thought. The Sokol Movement is considered to have been initiated by the foundation of the Prague Gymnastics Club by Miroslav Tyrš in 1862. The goal of Tyrš was to persuade people to practice gymnastics and improve all Slavic society in terms of culture and as nations. The mission of the Sokol Movement was defined as training its members morally, ethically and aesthetically through physical education in line with democratic principles towards national unity. Tyrš made use of German and Swedish gymnastics practices in line with the needs he pointed for his nation and soon achieved significant impact over Slavic people. Sokol spread around the world, particularly Central, Eastern and Southern Europe from early $20^{\text {th }}$ century on. Sokol symbolized the liberation from foreign domination of oppressed nations with a yearning for freedom and democracy and played a significant role on the development of a national Slavic conscience and nationalism from early stages on, setting an example to other nations. The organization of Slavs outside of Slavic land and other nations' efforts similar to Sokol have been the most important tools of national defense and people empowerment through physical education and sports. The enormous power of Sokol attained in a time period shorter than 50 years has sustained the attention of politicians and even when regimes changed, the Sokol Movement has remained a major part of governments' social policy. Thus, the strong and systematic structure of Sokol have been perceived as a threat by enemies of the nation and efforts were mobilized to passivate Sokol during times of invasion. Yet, although interruptions occurred at various times, the Sokol Movement achieved unity with the people particularly through Sokol Festivals and has lived until today. Today, Sokol is still a major component of Czech nationalism and continues to be a defender of national consciousness and democracy.
\end{abstract}

Keywords: Sokol, Czech Republic, Miroslav Tyrš, Physical education and sports, Nationalism

\section{Giriș}

Fiziksel kültürün önemli bileșenlerinden olan jimnastik, 18. yüzyıl sonları ile 19. yüzyıl başlarında birçok Avrupa ülkesinde, sağlıklı beden ve zihin bütünlügüne sahip olmanın bir yöntemi olarak ortaya çıkmıştır. Bu süreç içerisinde jimnastik, milliyetçiliğin de etkisiyle bağımsızlık mücadelesinin bir parçası olmuş ve birçok önemli akımın temsilcisi olmuştur (Riordan ve Krüger, 2003). Öncelikli olarak ülke savunması ve toplumun beden eğitimi yoluyla yeniden ayağa kaldırılması gibi benzer amaçlarla tekrar şekillenmeye başlayan beden eğitimi ve jimnastik anlayışı, Avrupa'da süregelen savaşların sonucu olarak farklı istikametlerde yol almıştır. Avrupa'daki gelişmeler sonucunda jimnastik; Almanya'da Basedow ile başlayan ve Jahn tarafından milli ve askeri bir şekle sokulan ve Amaros tarafından bazı değișiklikler yapılarak Fransa'ya ithal edilen ampirik Alman jimnastiği (Turnen) sistemi ve diğer taraftan fizyolojinin ve pedagojinin prensiplerine dayanan İsveç jimnastiği (Ling) sistemi olarak iki yola ayrılmıștır (Şinoforoğlu, 2020). Alman jimnastiği en büyük etkisini Orta Avrupa'da, başta Çek olmak üzere Sloven, Hırvat ve Sırp toplumlarından oluşan Slav halklarında göstermiştir. Bu bağlamda Avusturya-Macaristan İmparatorluğu bünyesindeki Çekler, 19. yüzyılın ikinci yarısından itibaren Alman jimnastiğinin milliyetçi ögelerinin ön plana çıkarıldığı ve Sokol hareketinin filizlendiği merkez olmuştur (Hoffmann, 2000; Pavlin ve Žvan, 2014). 
On dokuzuncu yüzyılın ilk yarısında, Slav halkları arasında en yüksek ekonomik ve kültürel gelişim düzeyine ulaşan Çekler, beden eğitimi alanı da dahil olmak üzere modernleşme yolunda çeşitli girișimlerde bulunmuşlardır. Bu girişimler arasında ülke genelinde en çok yayılan ve halen günümüzde varlığını sürdüren yapı ise Sokol olmuştur (Nolte, 2009). Sokol, Dr. Miroslav Tyrš tarafından 1862 yılında Prag'da kurulan bir Slav jimnastik hareketidir. Bu kapsamda, jimnastik ekipmanı, oyun ve belirli dövüş sanatları unsurları veya disiplinlerini içeren Sokol Sistemi, şenliklerle ve çeşitli organizasyonlarla ismini duyurmuştur. Diğer taraftan Sokol, ulusal bütünleșmenin bir aracı olarak toplumun fiziksel, ahlaki ve ruhsal açıdan ayağa kaldırılmasının ve bağımsızlık mücadelesinin gerçekleşmesinin hedeflendiği bir örgüt görünümündedir (Zmuda Palka ve Siwek, 2018). Çek Sokol Hareketi'nin kurucusu Tyrš'in amacı tüm Slavları aynı çatı altında birleştirmek, beden eğitimi yoluyla sosyal bir hareket yaratmak ve Sokol örgütünün Avrupa'da söz sahibi olmasını sağlamak olmuştur (Nolte, 2002a). Sokol hareketi, genel olarak liberal, ulusal ve bütünlük içinde yaşayacak bir Slav ırkı düşüncesine sahip olmuştur. Avusturya-Macaristan İmparatorluğu döneminde Sokol, farklı toplumlardaki Slav milliyetçiliğinin ve PanSlavizminin uyumlu ve karşılıklı olarak güçlendirerek, Slav kardeşliği ve işbirliği ruhu içinde, Slav halklarının fiziksel ve ruhsal kurtuluşunu sağlamayı hedeflemiştir. Slavlar böylece, fiziksel ve ahlaki açıdan güçlü bir ulusal yapı oluşturarak diğer halklar arasındaki konumlarını koruyabilmiş ve güçlendirebilmiştir (Troch, 2019).

Çek jimnastik hareketi Sokol, 19. yüzyılın ikinci yarısından itibaren ortaya çıkan Çek milliyetçiliğinin bir kitle hareketine dönüşmesinin de en önemli bileşendir. Günümüze kadar etkilerini sürdüren Sokol Hareketi, başta Avrupa olmak üzere dünyanın çeşitli bölgelerinde yaşayan toplumların sosyal, kültürel ve politik yapılanmalarına etkileri bakımından stratejik bir yapıya sahiptir. Sokol örgütünün; beden eğitimi ve spor yoluyla bağımsızlık mücadelesi ve yurt savunmasının bir aracı olarak kullanılması ile toplum üzerindeki yansımalarının Türkçe literatürde yeterince irdelenmediği görülmektedir. Bu kapsamda çalışmanın amacı Sokol hareketinin ortaya çıkışı, diğer ülkelerdeki yansımaları ve milliyetçilik düşüncesi üzerinden siyasi etkilerinin değerlendirilmesidir.

\section{Sokol Hareketi’nin Tarihi Gelişim Süreci}

18. ve 19. yüzyıllarda Avrupa'da jimnastik hareketleri; ulusal bütünleşmenin, bağımsızlık mücadelesinin ve aynı zamanda toplumun fiziksel, ahlaki ve ruhsal yeniden doğuşunun bir aracı olarak görülmüştür. Dönemin iki ana akımı olan Alman ve İsveç jimnastik akımları, ulusal kimliklerin ve karakterlerin hızlı bir biçimde şekillendirilmesinde önemli bir politik, öjenik ve askeri araç haline gelmiştir. Orta Avrupa Slavları bu sürece, modern egzersiz sistemlerinin sosyal inşasına ve kurumsallaşmasına "Sokol Hareketi” sayesinde dahil olmuşlardır (Pavlin, 2013; Zmuda Palka ve Siwek, 2018). Sokol kelimesi Slav dillerinde "şahin" anlamına gelmektedir. Hareketin sembolü ve Sokol kelimesinin anlamı olan şahin, Orta Çağ destanlarında Güney Slav kültüründeki şövalyelik yapan bir kahramanı sembolize etmektedir. Kelime anlamının köküne ve mistik yapısına uygun biçimde ortaya çıktığı 19. yüzyıldan itibaren Sokol, Slav yazınlarında ulusal kurtuluşun bir savaşçı şövalyesi olarak ifade edilmiştir. Hareketin ayrılmaz bir parçası ve en önemli propaganda araçları olan 
büyük jimnastik şenlikleri ve gösterilerine atıfla Sokol terimi İngilizce alanyazında "falcon" olarak geçmekte ve şahin anlamı dışında miting, toplantı veya gösteri anlamına da gelmektedir (Štěrbová ve Vlček, 2015; Troch, 2019).

1859 yllında Avusturya-Macaristan İmparatorluğu radikal bir değişim sürecine girmiş, dönemin Avusturya İçişleri Bakanı Alexander Bach, askeri yenilgiler ve başarısızlıkları nedeniyle görevden alınmıştır (Maxwell, 2009). 20 Ekim 1860'da ise Avusturya İmparatoru I. Franz Joseph, Ekim İzinnamesi ile parlamenter sistemi tekrar yürürlüğe koymuş ve bu değişim Avusturya halkının gergin siyasi rejimden ve partileşme sürecindeki kısıtlamadan kurtulmasını sağlamıştır (Türel, 2015). Bahsi geçen siyasal değişim vatanseverlik faaliyetlerine de pozitif bir etki yapmış, yeni kurulan sanat toplulukları ve yayımlanan dergiler birçok sanatçıyı ve genç kuşak yazarlarını ön plana çıkarmaya başlamıştır. Bu süreçte Prag'da, Tyrš'in beden eğitimi öğretmeni olarak yer aldığı Malypetr Enstitüsü ve Jahn'ın Alman jimnastiğine yeni bir form vererek geliştiren Eiselen'in kurduğu Schmidt Jimnastik Enstitüsü'nde, Turner'in Alman Jimnastik Birliği modeli örnek alınarak bir Alman-Bohemian Jimnastik Enstitüsü kurulmasına karar verilmiştir (Nolte, 2002a). Nitekim Eiselen'in jimnastik sistemi Tyrš’in etkilenim kaynaklarından biri olduğu gibi Sokol hareketinin başlıca egzersiz ve çalışmalarının da temelini oluşturmuştur (Bábela ve Oborný, 2018).

Sokol örgütünün bu erken yapılanma döneminde, düşünceyi destekleyen varlıklı Alman sponsoru Dresdner Bankası, örgütün yalnızca Alman Enstitüsü biçiminde kurulması gerektiğini belirtmiştir. Bu düşünceye karşı çıkan Tyrš, Alman sisteminden ve Almanlaşmaktan uzak durmak istemiş, gerekli hazırlıklarını da tamamladıktan sonra Bohemian Jimnastik Enstitüsü'nü kurmuştur. 16 Şubat 1862 tarihinde enstitünün ilk kurucu meclisinin belirlenmesinin ardından Avusturya-Macaristan İmparatorluğu bünyesinde, Sokol Hareketi'nin başlangıcı kabul edilen Prag Jimnastik Kulübü (Tělocvičná Jednota Pražská) kurulmuştur (Nolte, 2002b). Kulübün kuruluşunda, Dresdner Bankası'nın taleplerinden dolayı yeni sponsor arayışlarına girișen Tyrš’e finansal desteği sağlayan ve bir demokrasi destekçisi, asil bir hümanist ve finans alanında bir otorite kabul edilen Prag Bankası Direktörü Jindřich Fügner kurucu mecliste kulübün başkanı olarak seçilmiş, Miroslav Tyrš ise başkan yardımcısı ve kulübün idaresinden sorumlu kişi olmuştur (Bábela ve Oborný, 2018).

Prag Jimnastik Kulübü'nü 1862'de kurarak Sokol tarihini başlatan Miroslav Tyrš (1832-1884), entelektüelliğiyle tanınan bir sanat tarihçisi, spor organizatörü, politikacı ve Prag Üniversitesi profesörüdür. Tyrš'in Sokol Hareketi'ni kurma amacı, halkını jimnastiğe teşvik etmek ve tüm Slav halklarını kültürel ve ulusal bakımdan iyileștirmektir (LejkovaKoeppl, 1968). Sokol hareketinin görevi; üyelerini ahlaklı, etik ve estetik açıdan, demokrasi prensiplerine uyumlu biçimde beden eğitimi vasıtasıyla ulusal bütünlük yolunda eğitmektir (Savić, Zdravkovic ve Siljak, 2014). Bu bağlamda Tyrš tüm Slav halkları tarafından büyük bir kişilik olarak kabul edilmektedir. Çek ülkesinde yeni ortaya çıkardığı sistemle Tyrš, günümüzde halen Çekya ve Slovakya'da kullanılan beden eğitimi terminolojisinin de yaratıcısıdır (Lejkova-Koeppl, 1968). 
Sokol jimnastik sisteminin gelişmesi sürecinde Miroslav Tyrš, 19. yüzyıl Orta Avrupa'sında, farklı akımları izlemiștir. Alman jimnastik akımı Turnen ve kısmen İsveç jimnastiği Slavlar arasında Sokol örgütünde yaygın olarak görülmektedir (Pavlin, 2013). Sokol Hareketi, başlangıçta Friedrich Ludwig Jahn'ın öğretisi olan Alman Turnen hareketinden etkilenilmiş ve bir takım temeller esas alınmıştır. Alman ırkını bedenen ve ruhen savaşa hazırlama ve fiziksel olarak güçlendirme prensibini içeren Turnen'in temel egzersizlerini; yer hareketleri, oyun varyasyonları, koşular, atlamalar, atmalar, Jahn tarafından icat edilen aletlerle yapılan çalıșmalar oluşmaktadır. Ayrıca egzersizlerin bir kısmı gezi/gözlem ve gece yapılan aktivitelere dayanmaktadır (Vít ve Reguli, 2015). Jahn, Turnen akımını, Napolyon'un savaş literatürüne kazandırdığı "halk orduları" anlayışına uygun biçimde, vatanseverlik ve milliyetçilik düşüncesi temelinde, Alman halkının tamamının gerektiğinde ülkesini savunabilecek fiziksel, zihinsel ve ruhsal becerileri jimnastik yoluyla kazanması üzerine inşa etmiştir (Şinoforoğlu, 2020). Benzer biçimde Sokol da, üyelerini güçlü bir vücut ve zihne sahip olmaları için egzersiz yapmaya teşvik etmiş ve "ulusal ordu" oluşturulmasının temellerini beden eğitimi ve jimnastik vasıtasıyla atmaya çalışmıştır (Sak, 2012). Yurt savunmasının Sokol'un temel öncelikleri arasında olmasından dolayı Tyrš, 1866 Avusturya-Prusya savaşı esnasında, ulusal savunma eğitimlerinin, Sokol Birliği'ne de öğretilmesinin bir ihtiyaç olduğunu "Çek Ordusu İçin Komuta Terminolojisi" adlı eserinde ifade etmiştir (Tyrš, 1867'den aktaran Bábela ve Oborný, 2018). Nitekim Sokol Hareketi ilerleyen süreçte, Tyrš'in başlangıcından itibaren oluşturmayı düşündüğü Slav milliyetçiliğine dayalı ulusal hareketinin ayrılmaz bir parçası konumuna yükselmiştir (Štěrbová ve Vlček 2015).

İlk Sokol eğitimlerinde öncelikle yürüyüş, eskrim ve ağırlık kaldırma üzerinde durulmuş, ancak daha sonra egzersizlerin tekrarı ile elde edilen dayanıklılık ve güce odaklanan Turnen'e karşı Sokol, İsveç jimnastiğinde olduğu gibi bireysel ve grup olarak yapılan hareketlerin estetik niteliklerini de vurgulamayı uygun görmüștür (Sirotkina, 2017). Bu uygulamada Tyrš, fiziksel egzersizleri dört gruba ayırmıștır. Bunlar; jimnastik aleti ve başkasının etkisi olmadan kişinin bireysel yapabileceği egzersizler (yer hareketleri gibi), aletli çalışmalar, grup jimnastiği ve dövüş sporu olarak sıralanabilir. Ayrıca Tyrš, Sokol hareketini etik ilkeleriyle tanımlamış ve yaygınlaştırmıştır. Bu ilkeler; güçlü olabilme, aktif ve dayanıklı olabilme, bağımsız ve anavatana bağlı olma, gönüllü ve disiplinli olma, Sokol üyeleri ile kardeşlik ilişkisi içerisinde olma olarak ifade edilebilir (Kragujević, 2017).

Sokol birliğinin oluşum sürecinde, henüz daha Baron Pierre de Coubertin olimpizm düşüncesini ortaya koymadan, olimpik felsefenin izleri de yoğun bir şekilde görülmektedir. Tyršin, oluşturduğu sistemde 19. yüzyıl ana jimnastik akımlarının yanında Antik Yunan'dan, Helenizm düşüncesinden ve Antik Olimpiyat Oyunları'ndan ilham aldığı anlaşılmaktadır. Tyrš, Hod Olympický (Olimpiyat Bayramı) adlı eserinde de, Antik Yunan'da beden eğitimi kültürü, fiziksel egzersizlerin anlamı, bireysel ve sosyal uygulamalar hakkında bilgilere yer vermiștir. Coubertin'in “Olimpizm bir sistem değil, düşünce yapısıdır" sözünden yola çıkılacak olursa; Sokol Hareketi'nin vatandaşların ahlaki durumlarından kendisini sorumlu tutması ve bireylerin profili, kültürleri, kimlikleri, değerleri ve ideallerinin Sokol düşüncesine dayanması, Sokol ile olimpizm arasındaki 
ilişkinin anlaşılmasını kolaylaştıracaktır. Bu bağlamda Sokol Hareketi, Antik Yunan'daki areté anlayışında olduğu gibi, dünyayı algılama ve değerlendirmenin bir yolu olarak görülmekle birlikte ontolojik olarak da insana odaklanmış durumdadır. Tyrš’in kurduğu sistem düşünsel bazda antik kültürde ideolojik köklerini bulan bir eğitim ve kültür düzenidir (Černek, 2008). Kısaca Sokol Hareketi düşüncesi, bireylerin hem manevi duygularını hem de fiziksel aktivitelerini, ulusal duygularla sentezleyerek, kültürel iş birliği içerisinde, kişinin sahip olduğu uyum ideallerinden elde edilen özellikleri kapsayan geniş bir eğitim sistemi olarak tanımlanabilir (Kaimakamis, Dallas, Stefanidis ve Papadopoulos, 2011).

Nitekim fiziksel aktiviteler üzerine yapılanan Sokol düşüncesi eğitim müfredatında da kendisine yer bulmuş, özellikle Tyrš’ın felsefesine bağlı olarak kadınların beden eğitimi ve kamusal alana çıkarılmalarında önemli bir rol oynamıştır. Çek topraklarında jimnastik uygulamalarının okul müfredatlarına giriși 1848 Mart Devrimi'nden sonra kabul ediliyor olsa da 1869'da yürürlüğe giren eğitim kanununun ardından gerçek anlamda uygulanmaya başlandığı görülmektedir. Yeni müfredat kapsamında ilköğretim düzeyindeki erkek öğrenciler için 2 saatlik jimnastik dersleri verilmeye başlanmış, fakat kız çocukları derslere katılım sağlayamamıștır (Stepišnik, 1978 aktaran Pavlin, 2018). Slav toplumlarında Sokol hareketinin ortaya çıkışından kısa süre sonra tam anlamıyla müfredata giren okul jimnastiğinin amacı; vücudu güçlendirmek, kendine güveni artırmak, beden ve zihin bütünlüğünü geliştirmek ve cesaretli bireyler yetiştirmek olarak ortaya koyulmuștur. Derslerde serbest egzersizler, grup egzersizleri, ip tırmanışı, atlama, sopayla cismi uzağa fırlatma, kulplu beygir hareketleri gibi çeşitli formlarda çalışmalar yer alırken, Sokol'a özgü olarak da sopa ve diğer silah benzeri nesnelerle yapılan egzersizler ve grup halinde senkronize çalışmalar yapılmıştır (Pavlin, 2018; Sirotkina, 2017).

Tyrš, Sokol hareketinin doğduğu günden itibaren fiziksel egzersizlerin sadece erkekler için değil aynı zamanda kadınlar için de önemli olduğunu vurgulayarak ulusun sadece erkeklerden oluşmadığını vurgulamıştır. Çocukların Sokol disiplinini almaları gerektiğini ve vücut kültürünün erken yaşlardan itibaren öğretilmesinin en iyi anneler tarafından yapılabileceğini belirtmiștir. Bu düșünce kapsamında müfredat değişikliğinin olduğu 1869 yılında Prag Kadınlar ve Kız Çocukları Jimnastik Derneği kurulmuş ve Sokol fikri kadınlar arasında da yaygınlaştırılmaya çalıșılmıştır (Nolte, 1993). Sokol adına yapılan bu girişimin, kız çocuklarının gittiği okullarda beden eğitiminin tanıtılmasında konusunda büyük etkisi olmuştur (Burian, Waic, Barta ve Svoboda, 2012). Böylece kısa süre sonra kızlar için yalnızca temizlik ve dikiş gibi işlerin öğretildiği okullarda kızların da jimnastik derslerine katılmasına izin verilmiştir. Benzer biçimde Sloven topraklarında da kız çocukları 1883 yılından itibaren, ebeveynlerinin onaylaması şartıyla, jimnastik eğitimi almaya başlamışlardır (Pavlin, 2018). 1880'li yıllardan itibaren kızları da kapsayacak biçimde genişleyen derslerdeki mevcut egzersizlere, Sokol anlayışına uygun olarak, kızlar için dans, bayrak ve eşarplar ile yapılan özel egzersizler de eklenmiştir (Sirotkina, 2017). Kadın jimnastiğindeki gelişimin yansımaları ise Aralık 1897'de Çek Sokol Birliği'nin kadınlar için ayrı birliklerin kurulması çağrısıyla ve 1901 yılındaki 4. Sokol Festivali'nde kadınların ilk performanslarını ortaya koymalarıyla görülmüştür (Burian vd., 2012). 
Tyrš, düzenli olarak jimnastik eğitmenleriyle yapılan toplantılarda Sokol Birliği'nin tüm Bohemya'yı da kapsayan Çek bölgelerinde kurulması gerektiğini vurgulamıştır. Böylece Sokol Hareketi kuruluşundan itibaren hızlı bir yapılanma sürecine girmiş ve kısa sürede öncelikli olarak Çek bölgelerinde ardında da diğer tüm Slav halklarının yaşadığı bölgelerde yeni şubelerini açmaya başlamıştır (Bábela ve Oborný, 2018). Hareketin ilk yılı olan 1862'de yalnızca dokuz örgüt ve 265 yetişkin üyeden oluşan birlik (Jandásek, 1932) 1865 yılına gelindiğinde 1.949 üyeye ulaşmış, Moravya ve Silezya bölgelerinde açtığı yeni şubelerinin sayısı 1867'de on üçe yükselmiştir (Bábela ve Oborný, 2018). 1892'de Prag örgütünün, Moravya ve Silezya örgütleri ile birleşmesi sonucunda Çek-Slav Sokolları Federasyonu kurulmuş, 1904 yılında ise örgütler Çek Sokol Birliği adındaki tek bir çatı altında toplanmıștır (Arkayev, 1997). Daha sonra Dr. Miroslav Tyrš, Prag Bankası Direktörü Dr. Jindřich Fügner ile birlikte daha büyük adımlar atmaya başlamıştır. 2 Şubat 1908 tarihinde, Friedrich Ludwig Jahn tarafından başlatılan Alman "Turnbewegung” modeli örnek alınarak "All-Slav Sokol Birliği" Viyana'da kurulmuş ve Slav dili konuşulan tüm bölgelerde başarılı bir şekilde yayılmaya devam etmiştir (Nolte, 1996).

Sokol Hareketi, I. Dünya Savaşı'nın patlak verdiği dönemde 1.100 örgüt ve 130.000 yetişkin üyeye sahip bir birlik haline gelmiştir (Jandásek, 1932). I. Dünya Savaşı esnasında ise başta Çekler olmak üzere diğer Slav topluluklarını da bünyesinde barındıran AvusturyaMacaristan İmparatorluğu'nun başındaki Habsburg Hanedanlığı tarafından şüpheli ve düşmanca organizasyonlar olarak görülen Sokolların tüm faaliyetleri durdurulmuştur. Birliğin üyeleri de özel incelemeye alınarak sürekli gözlem altında tutulmuştur (Zec, 2015). Ancak tüm bu kısıtlamalara rağmen birçok Sokol üyesi, Çek ırkının Avusturya-Macaristan birliğinden ayrılıp Rusya tarafına geçmesi için birtakım çalışmalar yapmıştır. Ayrıca Sokol üyeleri, Habsburg Hanedanlığı'nın yıkılmasının ardından 1918 yılında kurulan Çekoslovakya devletinin ordularının ve yerel devriyelerin kurulmasına yardım etmişlerdir (Preclik, 2019).

I. Dünya Savaşı'nın ardından ortaya çıkan korku ve yeni bir savaş potansiyeli tüm dünyada olduğu gibi Çekoslovakya'da da hükümetin kitlesel beden eğitimi yoluyla ülkesini savunacak iyi askerler yetiştirme politikasına yönelmesine ve gençliğin beden eğitimine yoğun bir şekilde yönlendirilmesiyle sonuçlanmıştır (Prica, 2013). Böylece Sokol Hareketi devlet politikasıyla da uyumlu biçimde yeniden ön plana çıkmıştır. 1920 yılına gelindiğinde 2.630 örgüt ve 557.000 üyesiyle Sokol Hareketi savaş öncesi üye sayısının dört katına ulaşmıştır. Tüm iletişim ve ulaşım zorluklarına rağmen 1920'de Prag'da yapılan 7. Sokol Festivali'nde (Sokol Slet) 24.000 erkek, 15.000 kadın tarafından yapılan jimnastik gösterilerine ek olarak Prag sokaklarındaki zafer yürüyüşüne 300.000 kişi katılmıştır (Jandásek, 1932). 1920'den sonra 6 yıllık aralarla yapılmaya devam eden Sokol Festivallerine katılım giderek artmış 1938 yılında yapılan 10. Festival'e 350.000 üzerinde jimnastikçi ve 2 milyonun üzerinde seyirci katılmıştır (Czech Sokol, 2018). 10. Festival'den birkaç ay sonra Nazilerin Çekoslovakya'yı işgal etmesinin ardından Sokol liderleri toplama kamplarına gönderilmiş, tüm Sokol sermayesi ve tesislerine el konulmuştur (Gajdoš, Provaznikova, Bednar ve Banjak, 2012). Nazilerin mağlup edilmesinin ardından yeniden toparlanmaya başlayan Sokol organizasyonu ülkede demokrasiye karşı yeni bir tehditle 
yüz yüze gelmiştir: Komünizm (Lejkova-Koeppl, 1968). Çekoslovakya Sokol Birliği yönetimi, demokrasi prensiplerine aykırı oldukları gerekçesiyle komünizm fikri ile savaş sonrası kurulan Yugoslavya bünyesindeki Çekoslovakya Komünist Partisi'ne ve diğer totaliter Çek politikası olan faşizme karşı çıkmıștır (Burian vd., 2012). Başlangıçta Komünist Parti, Sokol Hareketi'ni kendi lehine kullanmayı planlamış ve 1948 yılındaki Sokol Festivali'ni bir propaganda aracı olarak görmüș ve yapılmasına izin vermiștir. Ancak festivalin komünist tiranlığına karşı bir ulusal manifestoya dönüșmesini, festivalin hemen ardından Sokol liderlerinin partiyle ortak çalışmayı kabul etmeyerek istifa etmeleri ve Komünist Parti'nin Çek Sokol Birliği'ni dağıtması izlemiştir. Anti-komünist aktiviteleri dolayısıyla birçok Sokol üyesi tutuklanmıș, tüm Sokol malvarlıklarına el konulmuş, liderleri sürgüne gönderilmiştir (Lejkova-Koeppl, 1968). 1948 yılından itibaren sosyalist rejimin beden eğitimi politikaları uygulamaya sokulmuş, eğitsel jimnastik yerini artistik jimnastiğe devrederek özellikle askeri olmak üzere kulüp tabanlı bir yapıya dönüşmüştür. Birleșik beden eğitimi ve spor düşüncesinden yola çıkılarak performansa dönük sınıflandırmaların yapılması ile yurtiçi ve yurtdışı turnuvalarına yönelik yoğun antrenman programlarının uygulanması, sporda kaliteyi yükseltmiștir (Gajdoš vd., 2012). Sokol temeli üzerinden yükselen Yugoslavya sporunun yükselişi ise ülkenin dağıldığı 1989'a kadar devam etmiștir.

\section{Sokol Hareketi'nin Diğer Ülkelerdeki Yansımaları}

Sokol akımının başlangıç dönemlerinde birçok Slav ülkesi Habsburg Hanedanı tarafından yönetilmiştir. Bu dönemde hanedanlık çatısı altında yaşayan Slavlar arasındaki ilk jimnastik toplulukları, 1860 ve 1861'de Avusturya-Macaristan İmparatorluğu'nda anayasal ve demokratik yaşamı getiren kanunun kabul edilmesinden sonra kurulmuştur. Bu yasanın kabul edilmesiyle politika, kültür, spor ve ticarete kadar tüm alanlarında sivil toplum örgütlerinin kurulmasına izin verilmiştir. Amatör jimnastik ve spor faaliyetleri bahsi geçen siyasi değişikliklerden önce yapılanmış olsa da, amatör jimnastik birliklerine resmi olarak kendi topluluklarını kurma firsatı yeni anayasanın ardından sunulmuştur. Demokratikleşmenin de etkisiyle sivil toplum örgütlerinde milliyetçi hareket süreçlerinin yeniden canlandığı ve ardından ittifaklara dayalı bir sivil toplum yapılanmasının oluşturulduğu görülmektedir. Bu durum, jimnastik dernekleri de dâhil olmak üzere diğer sivil toplum örgütlerine büyük fırsat tanımıştır. Böylece, Slovenler ve diğer Güney Slavlar ile Avusturya-Macaristan İmparatorluğu içinde ulusal mücadelenin ilanı yükselmeye başlamıştır (Pavlin ve Custanja, 2018).

Sokol hareketi kurucusu Miroslav Tyrš ve destekçisi Jindřich Fügner, Slav halkları arasındaki birliğe başlangıçtan itibaren önem vermiş, Slav ırkının yaşadığı ülkelerde birçok Sokol Birliği kurmuşlardır. Çeklerin ikamet bölgeleri dışındaki ilk örgüt 1 Ekim 1863 yılında Slovenya'da "Južni Sokol" adıyla kurulduktan sonra onu Hirvatistan (1874), Bulgaristan (1879), Ukrayna (1894), Sirbistan (1891), Polonya (1897) ve Slovakya (1918) şubeleri izlemiştir. Slav kökenli ülkeler dışında da yapılanmaya giden Sokol Birliği'nin Avusturya (1867), İsviçre (1868), Almanya (1889), Fransa (1891), İngiltere (1903), Arjantin (1908), Danimarka (1910) ve Kanada'da da (1911) örgütlendiği bilinmektedir (Bábela ve Oborný, 2018; Nolte, 2002a; Nolte 2002b). 
19. yüzyılın ikinci yarısında jimnastik toplulukları tüm Avusturya-Macaristan İmparatorluğu'nda kurularak yaygınlaşmaya başlamıștır. Bugünkü Slovenya topraklarında, 1862 ve 1863 yıllarında Ljubljana'daki iki jimnastik topluluğu olan Alman Turnverein ve Slovenya Južni Sokol (Güney Falcon) birlikleri, I. Dünya Savaşı öncesi, ulusal ve liberal bir sistem içinde kurulmuştur (Pavlin, 2013). Sloven toplumunda Sokol hareketi, eğitmenlere yönelik düzenlenen kursların da etkisiyle yayılan ve geliştirilen yeni bir alan ortaya çıkarmıştır. 1869 yılında aletsiz alıştırmalar konusundaki ilk eser Jimnastik Bilimi (Nauk o telovadbi) yayımlanmıș, direk ve çeşitli aletlerle yapılan egzersizleri kapsayan çalışmalar yaygınlaşmaya başlamıştır (Pavlin ve Čustonja, 2018). Ayrıca, Sokol'un gelişimi açısından 1896'dan sonra Viktor Murnik'in, eğitmenler için düzenlediği kurslar oldukça önemlidir. Verilen eğitimlerin içeriği, çalışma alanında profesyonelleşmenin temeli olan ve ayrıca diğer bölgeler ve ülkelerdeki Sokol hareketleriyle temasların temeli haline gelen Tyrš'ın Sokol sistemine dayandırılmıştır. Murnik'in teorik çalışmaları sayesinde, Sokol uygulamaları hem okulların müfredatlarında yer almış hem de yeni bir mesleki yapılanma ve sosyal aktivite ortaya çıkmıştır. Böylece Sokol hareketi Sloven topraklarında hızla yayılmaya ve sağlam bir zemin üzerine oturmaya başlamıştır (Pavlin, 2013; Savić vd., 2014). Slovenya'daki Sokol topluluklarının büyümesiyle 1905 yılında Sloven Sokol Birliği adıyla ulusal bir örgüt kurulmuş ve 1907 'de Uluslararası Jimnastik Birliği (FIG) bünyesine dahil olmuşlardır. Aynı yıl Prag'da FIG Dünya Artistik Jimnastik Yarışmaları'na katılan Sloven Sokol sporcuları, Murnik'in sistematik çalışmalarının ne kadar verimli olduğunu elde edilen madalyalarla göstermişlerdir (Pavlin ve Čustonja, 2018). I. Dünya Savașı'nın ardından Sloven, Hırvat ve Sırplar birleşerek Yugoslavya Krallığı'nı oluşturmuşlardır. Böylelikle 1919 yılında Sloven, Hırvat ve Sırp Sokol Birlikleri tek çatı altında toplanarak Yugoslav Sokol Birliği'ni kurmuşlardır (Pavlin ve Žvan, 2014).

Çek Sokol birliklerini örnek alarak kurulan bir diğer örgüt ise 1874 yılında Zagreb'de kurulan "Hrvatski Sokol u Zagrebu" (Zagreb Hırvat Sokolü) olarak bilinmektedir. Hırvatistan'daki ilk Sokol örgütünün kurucuları hem seçkin burjuva üyeleri (doktorlar, profesörler vb.) hem de diğer sosyal sınıflardan (zanaatkârlar, tüccarlar, kâtipler ve diğer devlet memurları) oluşmuştur. Burada aynı birlik çatısı altında toplanmak amacıyla sınıf ayrımı yapmaksızın her insanın yer alabildiği görülmektedir. Diğer taraftan artan üye sayısı, çeşitli sosyal etkinlikler ve aktiviteler Sokol birliğinin hızla organize olmasına ve büyümesine destek olmuştur (Borošak Marijanović, 2011). Sokol hareketinin spor alanında ülke çapında yaşattığı etkilerden biri de beden eğitimi ve sporun okullarda yer almasıdır. Hırvatistan'da beden eğitiminin gelişimi Hırvat Sokol hareketi sayesinde olmuş ve Hırvat Sokolu'nun 1874'te kurulmasıyla aynı yıl beden eğitimi Hırvat okullarında zorunlu ders haline gelmiştir. Bu sebeple, Hırvatistan beden eğitimi sisteminin kurulmasında Sokol'un büyük rolünün olduğu ortadadır (Škegro ve Čustonja, 2015). Diğer Slav topraklarında olduğu gibi Sokol, kurulduğu zaman Güney Slavlar arasında "ulus için fiziksel, ahlaki ve entelektüel eğitim" sağlama zorunluluğuna sahip olmuştur. Öyle ki, Sokol'un I. Dünya Savaşı'ndan önce özellikle gençler arasında gerçekleşen faaliyetleri oldukça etkin olmuştur (Nolte, 2002a). 
Sokol hareketinin büyümesiyle, 1904 yllında Sušak'ta (bugün ki Rijeka şehrinin bir bölümü), Hırvat Sokol Dernekleri Federasyonu kurulmuştur. İlerleyen süreçte 1907 yılında Zagreb'de yer alan birlik adını Hırvat Sokol Federasyonu olarak değiștirmiştir. Federasyonun esas amacı farklı Sokol birliklerini bir araya getirerek faaliyetlerini birbirine entegre etmek, diğer ülkelerdeki Sokol federasyonları ile bağlantılar kurmak ve Sokol hareketinin ideallerini topluma benimsetmektir (Čustonja, 2014). Hırvat Sokol Federasyonu diğer Sokol birliklerini bir araya getirmenin yanında, Hırvat jimnastik hareketinin gelişimi ve tanıtımı için uluslararası arenalarda da yer almıştır. Örneğin, Hırvat Sokol Dernekleri Federasyonu, 1907 yılında merkezi Paris'te bulunan Uluslararası Jimnastik Federasyonu'na üye olmuş ve 1911 yılında Hırvat jimnastikçiler Torino/İtalya'da düzenlenen Avrupa Jimnastik Şampiyonası'nda yarıșmışlardır. Böylelikle Hırvat spor tarihinde ilk kez Hırvat yarışmacılar resmi uluslararası bir organizasyonda tek bir bayrak altında bulunmuşlardır (Borošak Marijanović, 2011). Bu noktada, Hırvatistan'da modern sporun kökleri, Çek topraklarında ortaya çıkan Sokol hareketiyle oluşmaya başlamış ve Hırvat Sokolu'nun büyümesiyle, 1914 yılına kadar günümüz Hırvatistan ve Bosna Hersek topraklarında 169 yerel organizasyon kurulmuştur (Hrstić ve Mustapić, 2015).

I. Dünya Savaşı'nın başlangıcında, yaklaşık 180 topluluk ve 15.000- 20.000 civarında üyesi bulunan Hırvat Sokol hareketi, jimnastiğe ek olarak, ulusal bağlamda politik ve ideolojik motivasyon ve hedeflere de sahip olmuştur. Özellikle Almanlaşmaya ve Macarlaşmaya karşı mücadele, ulusal bilincin güçlendirilmesi ve korunması yönünde hamleler yapılmış, Hırvatistan ve Avusturya - Macaristan İmparatorluğu içindeki diğer Slav ülkelerinin daha iyi bir yasal konuma ulaşması için mücadele edilmiştir (Pavlin ve Čustonja, 2018). Ulusal çıkarları koruma amacıyla jimnastik etrafinda örgütlenen bu sosyal örgütler, Macarlaştırma ya da Almanlaştırma baskılarına karşı koyarak Slav ruhunun varlığını kanıtlama ve değerlerini koruma adına direnç göstermişlerdir. Bu noktada Hırvat Sokol Hareketi, önce șehirlerde ve daha sonra köylerde kurulan birlikler tarafindan temsil edilen benzersiz bir sistemin parçası olmuştur. Böylelikle, milli bütünlüğün korunması ve ulusal çıkarların savunulması açısından, beden eğitimi kurumları ve faaliyetleri, ulusal direnişin güçlenmesi için bir araç haline gelmiştir.

Sokol örgütünün varlığı ve çalışmaları, Slav ulusunun ideolojik, politik, kültürel, manevi ve spor politikalarında yoğun bir şekilde hissedilmiştir. Bu durum, Sırbistan beden eğitimi tarihinin de önemli bir bölümünü temsil etmektedir. Sirp Sokol hareketinin kurucusu Dr. Popović'in, Joseph Kraus isimli Çek bir hastasının önerisi ile 1882 yılında kurduğu "Belgrad Sokol Jimnastik Birliği" kısa sürede gençler arasında popülerlik kazanmıştır. Bu birlik 19 Ocak 1904 tarihinde kurularak resmi otoriteler tarafından da onaylanan "Sırp Sokol Birliği”nin temelini olușturmuștur. Sırp Sokol hareketinin öncüsü Dr. Popović'in öncelikli hedefi ise, diğer Slav topluluklarındakilere benzer biçimde, Sokol fikrini Sırplar arasında yayarak Avusturya-Macaristan boyunduruğu altındaki ulusu tek bir topluluk altında birleştirmek ve halktaki özgürlük düşüncelerini uyandırmak olmuştur (Vukašinović vd., 2016). Başlangıçtan itibaren Sırp Sokol hareketi, kamusal yaşam üzerinde önemli bir etkiye sahip olan Sokol mitingleri, gösterileri ve şenlikleri vasıtasıyla ulusun her bireyini egzersiz yapma ve rekabet etmeye yönlendirmiştir (Savić vd., 2014). 
Savaşın ardından 1 Aralık 1918 tarihinde Hırvat, Sloven ve Sırpların birleșerek Sırp, Hırvat ve Sloven Krallığı'nı kurmasıyla tüm Hırvat örgütleri 1919 yılında kurulan Yugoslav Sokol Birliği çatısı altında faaliyetlerine devam etmiştir. Ancak, 1922 yılına gelindiğinde, Hırvat Sokol Birliği yeniden kurulmuş ve Hırvat ulusunun benzersizliğini savunmuştur (Pavlin ve Custanja, 2018). Hırvatistan'daki spor faaliyetlerinin en başından beri siyasete tabi olduğu ve ulusal ideolojilerin yayılması ama cına hizmet ettiği söylenebilir. 1929 yılında diktatörlüğünü ilan ederek Yugoslavya Krallığı'nı kuran I. Alexander mevcut Hırvat Sokol derneklerini yasaklamış ve Yugoslav ideolojisini yaymanın bir aracı olarak Yugoslavya Sokol Birliği'ni desteklemiştir (Hrstić ve Mustapić, 2015; Sesum ve Milosevic, 2014). Sokol bünyesinde halkı eğitmek ve fiziksel olarak güçlendirmek amacıyla devletin kültür politikalarının Sokol'un eğitim çalışmaları altında gerçekleştirilmesi için açılan Sokol Evleri, Yugoslav ideolojisinin yaygınlaştırılmasının merkezine yerleştirilmiştir. (Prica, 2013). 29 Haziran 1929'da Zagreb'te yapılan Yugoslav Sokol Birliği'nin kuruluş toplantısının bildirgesinde Slavizm olgusu ve tek bir Slavcılık vurgusu üzerinde durulmuş (Gajdoš vd., 2012), birleşimin ana prensibi ise "tek ulus, tek devlet, tek Sokol" olmuştur (Pavlin ve Čustonja, 2018). Yeni Sokol tüzüğü, Yugoslav gençliğinin fiziksel olarak sağlıklı, güçlü ve ulusal bilince sahip olarak yetiştirilmesi üzerine odaklanmıştır. Tek tip kırmızı gömlekleri ile "Yugoslav Davası"nın yılmaz savunucularının sloganı "sağlam bedende güçlü zihinler" olmuştur (Bábela ve Oborný, 2018). Güney Slav halklarında kitlesel beden eğitiminin tohumlarını eken, toplumda eşitsizliğin giderilmesi, kadınların özgürleştirilmesi ve toplum sağlığının sürdürülmesini amaçlayan Sokol hareketi mirasının günümüze kadar sürdürüldüğ̈̈ görülmektedir (Zec, 2015).

Hızlı bir gelişim göstererek Slav topraklarının tamamına yayılan Sokol hareketi ulus devletlerin başta askeri amaçlar doğrultusunda beden eğitimi ve spor odaklı fiziksel aktivite arayışlarında Alman ve İsveç jimnastiğine de bir alternatif oluşturmuştur. Çek topraklarında ortaya çıktığı 1860'lı yıllardan itibaren kısa sürede önce Avrupa'da ardından da deniz aşırı ülkelerde öncelikli olarak Slavlar tarafından uygulanmış ardından da ilgili devletlerdeki ana jimnastik akımları arasındaki yerini almıştır (Kaimakamis vd., 2011). 1867'den itibaren önce Polonya ve Bulgaristan'da boy göstermeye başlayan Sokol örgütlenmeleri I. Dünya Savaşı öncesinde Rusya'da kendisine yer bulmuştur. Özellikle Sokol üyeleri ve eğitmenlerinin Rus liselerinde ve askeri okullarında beden eğitimi derslerinden sorumlu oldukları görülmektedir (Lejková-Koeppl, 1968). Bu durum 1910'dan itibaren Rusya'da geçerli jimnastik sistemi olan Alman jimnastiğinin yerini Sokol jimnastiğine bırakmasıyla sonuçlanmıştır. Ancak 1917'de gerçekleșen Bolşevik Devrimi'nin ardından yeni yönetimin tehdit olarak algıladıkları jimnastik gruplarını dağıtarak, üyeleri ve eğitmenlerini sürgüne göndermesi sonucu Sokol jimnastiği Rusya'daki etkisini kaybetmiştir (Sirotkina, 2017).

Aynı dönemde Sokol hareketinin Avusturya, İngiltere, Almanya, Fransa, Belçika, İsviçre, İsveç, Macaristan, gibi Avrupa ülkelerinin yanında ABD, Kanada, Brezilya, Arjantin, Avustralya gibi deniz aşırı ülkeler ve kolonizasyon faaliyetlerine bağlı olarak bazı Afrika ülkelerinde de örgütlendiği bilinmektedir (Lejková-Koeppl, 1968). Avrupa dışındaki ilk Sokol örgütü 1865 yılında St. Louis/ABD’de, Çek ve Slovak göçmen grupları tarafından, 
Sokol'un ahlaki, fiziksel ve sosyal temelleri üzerinde yapılandırılmıștır. 1878 yılında ise Şikago'da hareketin merkezi örgütlenmesi olan Sokol Ulusal Birliği kurulmuştur (Burian vd., 2012). 20. yüzyıl başından itibaren tüm dünyadaki Sokol örgütlerinin etkileri Erken Cumhuriyet Dönemi'nde Türkiye'de de görülmektedir. Mehmet Emin, Türk Ocakları'nın Sokol Cemiyeti'ne yakın bir gayeyi benimsemesi gerektiğini, bu amaç doğrultusunda yapılacak faaliyetlerin beden eğitimi konusunda yüksek fayda getireceğinden bahsetmektedir ([Erişirgil], 1927). Türkiye'de beden eğitimi, spor ve olimpik hareketin öncüsü Selim Sırrı Tarcan, Sokol teșkilatının örnek alınarak Türkiye'de benzer faaliyetlerin yapılabileceğini savunmuştur. Türk Ocakları Merkez Heyeti'ne verdiği raporda Sokolların Çekoslovakya'da yaptıklarının Türk Ocakları'nda yapılabileceğini, zaman kaybetmeden Ocaklar'ın jimnastik teşkilatlanmasına başlaması gerektiğini belirtmiş, gençliğin bu jimnastik faaliyetlerini milli bir vazife olarak uygulamasına vurgu yapmıştır ([Tarcan], 1928). Yapılacak faaliyetlerin öjenik, politik ve ideolojik etkilerini ise Sokol hareketinin kurucusu Tyrš’in şu sözleriyle ifade etmiştir: “Bir milletin bugünü ve istikbalini garantiye alacak olanın onun parlak mazisi değil, mevcut dayanıklılığı ve zindeliği olduğunu bilmek gerekir." ([Tarcan], 1930).

\section{Sokol Düşüncesinde Milliyetçilik ve Politik Yansımaları}

Orta ve Güney Avrupa Slavları'nın jimnastik öncüsü olarak bilinen Sokol hareketi, Fransız burjuva devrimi ve demokrasi prensiplerine dayanarak; öncelikli olarak özgürlük ve ulusallığı isteyen, kadın ve erkek, köylü ve kentli, sermayeci ve işçi, özgür ve eşitlik isteyen tüm halklara açık bir görünüm sergilemiștir. Sokol hareketinin amacı, modernizmin sihirli kelimeleri olan erdemli, doğru, sorumluluk sahibi, etik ve ahlaki bütünlüğe değer verme yoluyla sürekli ilerleme ve gelişim gösterme idealinin peşinden giden toplum yaratmaktır. Sokol hareketinin ana enstrümanı olan fiziksel aktiviteler ise toplumun güçlü ve sağlıklı kalması ile sürekli gelişiminin garantörü olmuştur. Sokol hareketinin kurucusu Miroslav Tyrš örgütünü kuruluş gerekçesini şu cümleyle açıklamıştır: "Evrensel hayatta kalma yasası ışığında, fiziksel ve ahlaki değerlerini ihmal etmiş uluslar ve toplumlar, var olabilme ve hayatta kalma mücadeleleri sonucunda, yıkılmakta ve yenilmektedirler." Bu bağlamda Tyrš ve dolayısıyla Çek Sokol'u, Slav ırkının ayağa kaldırılması amacıyla tüm Slavların Sokol adı altında birleștirilmesinin çağrısında bulunmuştur (Kaimakamis vd., 2011; Pavlin, 2008; Pavlin, 2013).

Hareketin en önemli görevi daha üretken, gerektiğinde kendisini ve ülkesini savunabilecek sağlıklı nesiller yetiştirmek olarak belirlenmiştir. Bununla birlikte halkı fiziksel olarak güçlendirmek, moralini yükseltmek ve gençliği dinamik tutarak Slav kültürünü korumak diğer hedefler arasında olmuştur (Gajdoš vd. 2012). Tyrš, Sokol düşüncesinin propagandasını yapmak amacıyla Çek Sokol'unu kurduğu 1862 yılından itibaren landpartiemi adıyla bilinen uzun doğa yürüyüşleri içeren geziler düzenlemiştir. Kültürel-eğitsel bir karaktere sahip ve halkta vatansever bilinci güçlendirmek amaciyla düzenlenen gezilerin ilkinde yer alan 200 katılımcı geleneksel Sokol üniformaları giymiş, Prag çevresindeki anıt ve dini alanları ziyaret etmiştir (Bábela ve Oborný, 2018). Ayrıca geziler ulusal farkındalığı güçlendirmeyi amaçladığı kadar yeni Sokol örgütlerinin kurulmasını da teşvik etmiștir (Martínková, Klír ve Swierczeková, 2013). 
Sokol'un hedeflerinin Slav ırkında yaygınlaștırılması ve benimsenmesi ile halkın birbirine kenetlenmesinin temel aracı ise Slet adındaki Sokol Festivalleri olmuştur. Slet terimi ise dünyadaki tüm Slav topluluklarının bir hedefe doğru birlikte hareket etmesini tanımlayan Çekçe slet sa kelimesine dayanmaktadır. Pan-slet ise, Sokol çatısı altındaki tüm Slavların katıldığı jimnastik festivalini ifade etmektedir (Gajdoš vd. 2012). Halka açık ilk açık alan egzersizleri 1867 yılında Rohanský'de yapılırken, 1882'de Prag-Střelecký Adası'nda düzenlenen ilk Slet'in ardından Orta Avrupa'ya yayılan Sokol festivalleri; tüm katılımcıların gösterişli bir törenle karşılandığı, konuşmalar, tiyatro ve kitle gösterileri ile jimnastik yarışmaları etkinliklerini içermiştir. 696 jimnastikçinin 2.500'ü aşkın seyirci önünde yaptığı jimnastik egzersizlerini içeren ilk şenlik, 1.600 Sokol üyesinin üniformalarıyla geçiş yaptıkları tören alayını da barındırmıștır. İlk organizasyonun ardından katılımcı sayısı sürekli artan şenlikler, Tyrš'in "Her Çek bir Sokol'dür!" sloganının da etkisiyle kısa sürede Çek topraklarından çıkarak imparatorluk sınırlarının ötesine ulaşmış, siyasi ve politik etkileri vasıtasıyla yalnızca büyük bir spor etkinliği değil, aynı zamanda Slav kültürünü dünyaya tanıtmak için eşsiz bir fırsat olarak görülmüştür (Kozáková,1994; Viktorovich, 2014). Periyodik aralıklarla düzenlenmesi planlanmış olsa da çeşitli nedenlerle düzenli olarak yapılamayan şenliklerin Çek Sokol Birliği tarafından 1907'de yapılan beşincisine Slovenya, Sırbistan, Hırvatistan, Bulgaristan ve Rusya gibi Slav ülkelerinin yanı sıra Fransa, Belçika, İtalya, Lüksemburg, Macaristan, Hollanda ve Amerika'dan da olmak üzere 12.000'i aşkın üye katılmıştır. Aynı yıl Slovakya, Hırvatistan ve Slovenya birlikleri, Slav Sokol Federasyonu'nu kurmuş, 1910'da Bulgaristan, Polonya ve Sırbistan, 1912'de ise Rusya, federasyon çatısı altına girmişlerdir. Tüm Slav ülkelerinin federasyon çatısı altında birleşmesi sonucu Sokol aracılığıyla; jimnastik ve kültürel etkinlikler ile ulusal kurtuluş ve özgürlük hareketleri yayılmaya başlamıştır (Polidoro, 2000; Waic, 2013).

Sokol'un düşünsel temellerinde bulunan kurtuluş ve özgürlük hareketlerinin yansımaları I. Dünya Savaşı'nda kolaylıkla takip edilebilmektedir. Savaş yıllarında Sokol hareketinin tüm aktiviteleri durdurulmuş olmasına rağmen, savaş esnasında birçok Sokol üyesi Çek halkının Avusturya-Macaristan İmparatorluğu'ndan ayrılması için çalışmalar yapmış, Slovakların Macar istilasından kurtulmasında aktif rol oynamışlardır. Üyelerinin savaş yıllarındaki etkin rollerinin etkisiyle 1918 yılında kurulan Çekoslovakya'nın yeni hükümetinin desteğini alan Sokol, savaşın ardından eskisinden çok daha güçlü bir yapılanmaya sahip olmuştur. Tüm olumsuzluklara rağmen 1920 yılında örgüt sayısı 2.630'a, üye sayısı ise 557.000'e yükselmiştir (Jandásek, 1932). Özellikle Çekoslovakya'nın ilk Başbakanı Tomáš Garrigue Masaryk, hareketin en büyük destekçilerinden biri olmuş, Sokol Hareketi, altın çağını I. ve II. Dünya Savaşı arasındaki dönemde yaşayarak milyonlarca üyeye sahip bir örgüt haline gelmiștir (Grexa ve Strachová, 2011). Bu dönemde, Sokol'un vücut kültüründe yarattığı etki spora da yansımış, Çekoslovakya iki savaş arası dönemde, başta olimpiyat oyunları olmak üzere, uluslararası spor organizasyonlarında önemli başarılara imza atmıştır. Özellikle jimnastikçiler başta olmak üzere 1924 Paris Oyunları'ndan itibaren olimpiyat kürsüsünde kendisine yer bulan Çek sporcular, en büyük süksesini 1936 Berlin Olimpiyat Oyunları'nda yapmışlardır. İki güçlü jimnastik sistemi, Alman Turner ve Çek Sokol'unun mücadelesine sahne olan oyunlar 
(Riordan ve Krüger, 1999), Hitler'in propaganda amaçlarını zedelediği gibi Sokol hareketinin, kafasındaki işgal planları için bir tehdit oluşturduğunun da farkına varmasını sağlamıştır.

1938 Pan-Sokol Sleti'nden birkaç ay sonra Hitler ordusunun Çekoslovakya'yı işgal etmesinin ardından, Sokol'un savaş alanındaki etkisine hakim Nazi işgalcileri, Çekoslovak Sokol Birliği'nin tüm kaynaklarına el koyarak örgüt liderlerini toplama kamplarına göndermiş ve çoğunu öldürtmüştür. Sokol hareketinin ülke dışında sürdürülmesi sorumluluğunu Slovak ve Amerikan Sokol örgütleri üstlenirken (Gajdoš vd., 2012), Çekoslovakya'da bulunan üyeler özgürlük mücadelelerine devam ederek faşizme karşı mücadelelerini sürdürmüşler, Hitler'in en üst düzey subaylarından Reinhard Heydrich'e 1942 yılında Prag'da düzenlenen suikastta etkin rol oynamışlardır. Nazilerin suikasta misillemesi oldukça sert olmuş, art arda yapılan operasyonlarla yakalanan çoğu Sokol üyesi 288 kişinin toplama kamplarına gönderilerek infaz edilmesini (Burian, Knizek, Rajlich ve Stehlik, 2007), Sokol kökenli gençlik ve jimnastik örgütleri ile beden eğitimi öğretmenlerinin oluşturduğu birliklerin yasaklanması takip etmiştir (Dimond, 2007).

Oluşturdukları tehdit üzerine tüm faaliyetleri savaş süresince yasaklanan Sokol, savaş sonrası yeniden yapılanmıştır. Ancak 1946 seçimlerinde \%38 oy alarak ülkedeki en büyük parti durumuna gelen Komünist Parti'nin 1948'de darbe yaparak yönetime el koymasıyla geçilen komünist rejim özgürlükleri yeniden tehdit etmeye başlamıştır. 19-27 Haziran 1948'de Prag'da gerçekleştirilen 11. Slet, komünist rejim tarafından destekleniyor olsa da komünizme karşı çıkan üyelerin çeşitli sloganlarla rejimi protesto ederek alanı terk etmesi sonucu 200 üye tutuklanarak cezalandırılmış, şenlikler ise durdurulmuştur (Burian vd., 2012; Vit ve Reguli, 2015). Komünizm rejimi altında durdurulan şenlikler 1953 yılından itibaren Spartakiades olarak tanıtılmaya başlanmış, ilk Spartakiades ise 1955 yılında düzenlenmiştir. İsmini Roma döneminde köleliğe direnen Spartacus'ten alan organizasyonlar, komünist beden eğitimini sistemini yansıtmakla birlikte Sokol'un komünist rejimin propaganda aracına evrilişinin de izlerini taşımaktadır (Kaimakamis vd., 2011). Çekoslovakya'nın kurtuluşunun onuncu yılı olan 1955'te düzenlenen ilk Spartakiades, 200.000'in üzerinde izleyici ve geçit törenindeki yarım milyondan fazla çocuk, genç ve yetişkin üyenin katılımıyla gerçekleşmiştir (Gajdoš vd., 2012). 1957 yılında kurulan Çekoslovak Beden Eğitimi Birliği ise sosyalist rejimin beden politikalarının da yönlendirici organı olmuştur (Sekot, 2010). Birliğin temel amacı komünizm idealleriyle donatılmış sosyalist beden eğitimi sistemini toplumun her kademesinde derinlemesine işlemek olmuştur (Gajdoš vd., 2012). Komünist rejimin Sokol düşüncesine düşman olduğu bu dönemde, Sokol geleneği uzun yıllar boyunca yalnızca sosyalist olmayan ülkelerdeki üyeleri sayesinde varlığını sürdürmüștür (Burian vd., 2012). Bu sistem komünist rejimin yönetimi altında 1989 yılındaki Kadife Devrim'e kadar devam etmiştir. Komünizmin son bulmasıyla Sokol başarılı bir şekilde kendisini yenilemiş, halkın ulusal bilinci yeniden kazanmasının ve demokrasinin gelişimi için etkinliklerine devam etmiştir (Kaimakamis vd., 2011). Devrimin ardından Çekoslovakya'daki tüm mülklerini geri almak için mücadeleye başlayan Çek Sokol Organizasyonu (ČOS) yöneticileri 1991 yılında Sokol Festivalleri'nin yeniden yapılmasını kararlaştırmış ve 12. Festival 1994 yılında 23.000 jimnastikçinin 
katılımıyla yapılmıştır (Gajdoš vd., 2012). 6 yıllık periyotlarla yapılmaya devam edilen festivallerin Sokol Hareketi'nin kuruluşunun 150. yılının kutlandığı 2012 Festivali'ni, ülkenin 100. kuruluş yıldönümünde yapılan 2018 Festivali izlemiştir (Czech Sokol, 2018). Bir sonraki festivalin ise 2024 yılında yapılması planlanmaktadır.

\section{Sonuç}

Avrupa'da 19. yüzyıldan itibaren yükselmeye başlayan beden eğitimi ve jimnastik akımları farklı ülke ve toplumlarda kendi ihtiyaçlarına göre şekillenmiş, Slav topraklarında ise kendisini Sokol Hareketi'nde bulmuştur. Sokol'un kurucusu Miroslav Tyrš AvusturyaMacaristan İmparatorluğu bünyesindeki tüm Slav halklarını birleştirme düşüncesinden yola çıkarak Slav milliyetçiliğini, kardeşlik ve işbirliği ruhu içinde yükselterek fiziksel ve ahlaki bakımdan güçlü bir ulusal yapı oluşturmayı hedeflemiştir. Tyrš, Slavların güçlü, cesaretli, asil ve çalışkan bir ırk olmaları için gerekli olan fiziksel ve moral güce ancak beden eğitimi ve spor yoluyla ulaşılabileceğini vurgulamıştır. Alman ve İsveç jimnastiği egzersizleri üzerinden yeni bir form kazandırılan fiziksel aktiviteler; Sokol akımının temel taşını oluşturmuş, eğitimden sosyal hayata kadar birçok farklı alanda kendisine yer bulmuştur. Kısa süre içerisinde önce tüm Slav topraklarında ardından da diğer ülkelerde yapılanmaya giderek hızlı bir gelişim gösteren Sokol Hareketi geniş bir coğrafyada örgütlenmiştir. Özellikle Orta, Doğu ve Güney Avrupa ülkelerinde 20. yüzyılın başından itibaren ana jimnastik akımı konumuna gelerek beden eğitimi sistemlerinin ve sportif başarının tabanını oluşturmuştur. Sokol hareketinin güçlenmesi, yarışma ve festivaller ile ulusal ve uluslararası organizasyonlar vasıtasıyla Slav ırkının kendisini tanıtma ve propagandasını yapma şansını tanımıştır. Olimpiyat oyunları ile kıyaslanabilecek düzeyde kendi döneminin en büyük organizasyonlarından olan Sokol Festivalleri birçok ülke tarafından örnek alınmıș, Türkiye'de dahil olmak üzere benzer örgütlenmelerin ve festival organizasyonlarının yapılması tartışmalarının da odak noktası olmuştur. Yüzbinleri aşan kitlelerin katıldığı festivaller her ne kadar düzenli olarak yapılamasa da savaş dönemleri hariç günümüze kadar varlığını sürdürmüştür.

Başlangıçtan itibaren milliyetçi unsurlarla donatılmış olan Sokol hareketinin özellikle Slav ülkelerinde olmak üzere politik açıdan da önemli roller üstlendiği görülmektedir. Politik ve siyasi bunalımlar yaşayan halk, Sokol hareketi ile kendini yeniden bağımsız ve moral olarak güçlü hissetmeye başlamıştır. Özellikle Sokol üyelerinin savaşlarda üstlendiği aktif roller, Güney Slavlarının bağımsızlık mücadelelerin simgeleri arasında yer almıştır. Nitekim gerek düşmanlar gerekse Slav hükümetleri Sokol'u her zaman politik ve siyasi bir güç olarak görmüş ve kendi çlkarlarına uygun biçimde yönlendirmeye ya da yönetmeye çalışmıștır. Yugoslavya döneminde komünist rejim altında eksenini kaybetme tehlikesi yaşamış olsa da 1989 'da rejimin yıkılmasının ardından kısa sürede özüne dönen Sokol, ulusal bilincin en güçlü savunucularından biri olarak karşımıza çıkmaktadır. Çek Miroslav Tyrš`in öncülüğünde ortaya çıkan, farklı yönetim sistemleri altında her zaman özgürlüğü, demokrasiyi ve Slavizmi savunarak Slavlar ile özdeșleșen Sokol Hareketi günümüzde halen Çek ulusunun sosyal yapı taşlarından birini oluşturmaya devam etmektedir. 


\section{Çıkar Çatışması}

$\mathrm{Bu}$ makalenin yayınlanmasıyla ilgili yazarlar arasında herhangi bir çıkar çatışması bulunmamaktadır.

\section{Yazar Katkıları}

Araştırma Fikri: AU; Araştırma Tasarımı: AU, TŞ; Literatür Analizi: AU, TŞ; Makale Yazımı: AU, TŞ; Eleştirel İnceleme: TŞ

Yazışma Adresi (Corresponding Address):

Dr. Aylin UĞURLU

Gazi Üniversitesi Sağlık Bilimleri Enstitüsü, ANKARA

ORCID: 0000-0002-5148-7061

E-posta: ugurlu.aylin@gmail.com 


\section{Kaynaklar}

1. Arkayev, L. (1997). Centennial anniversary of first championship of Russia on Gymnastics. Theoria Praktika Fycicheskoy Kultuci, 11, 2-3.

2. Bábela, M. ve Oborný, J. (2018). Dr. Miroslav Tyrš - Father of the Sokol and philosophy of the Sokol. Science of Gymnastics Journal, 10(2), 313-329.

3. Borošak-Marijanović, J. (2011, Ağustos). Sokol flags - The symbols of Croatian Sokol movement to 1914: The Sokol Movement as a component of national and European integration at the beginning of the 20th century. 24th International Congress of Vexillology sunulan bildiri, North American Vexillological Association/Washington, D.C., USA.

4. Burian, M., Knizek, A., Rajlich, J. ve Stehlik, E. (2007). Assassination: Operation Anthropoid 19411942. Prague: Ministry of Defence of the Czech Republic.

5. Burian, M., Waic, M., Barta, M. ve Svoboda, L. (2012). Pod kř́ílly Sokola. Praha: Vojenský historický ústav; Ústav pro studium totalitních režimů.

6. Černek, M. (2008). Sokolství a olympismus. Tělesná Kultura, 31(1), 48-56.

7. Čustonja, Z. (2014). Hrvatski Sokol do prvoga svjetskog rata. Pavlin. T, (Ed.), Naša pot, 150 let ustanovitve južnega Sokola in sokolskega gibanja içinde (s. 84-100). Ljubljana: Fakulteta za šport.

8. Czech Sokol (2018). XVIth All-Sokol Slet 2018. Prag: Czech Sokol.

9. Dimond, M. (2007). The Sokol and Czech nationalism, 1918-1948. M. R. Cornwall ve J. W. Evans, (Ed.), Czechoslovakia in a Nationalist and Fascist Europe 1918-1948 içinde (s. 185-205). Oxford: Oxford University Press.

10. [Erişirgil], Mehmet Emin. (1927). Türk Ocakları. Hayat, 1(20), 1.

11. Gajdoš, A., Provaznikova, M., Bednar, K. ve Banjak, S. J. (2012). Sokol Slets: The essence of gymnastics in Czechoslovakia, Czech and Slovak Republic. Science of Gymnastics Journal, 4(3), 73-82.

12. Grexa, J. ve Strachová, M. (2011). Dějiny sportu. Přehled světových a českých dějin tělesné výchovy a sportu. Brno: Masarykova univerzita.

13. Hoffmann, D. L. (2000). Bodies of knowledge: physical culture and the new Soviet person. Washington, D. C.: National Council for Eurasian and East European Research (NCEER).

14. Hrstić, I. ve Mustapić, M. (2015). Sport and politics in Croatia-Athletes as national icons in history textbooks. Altre Modernità, 14, 148-165.

15. Jandásek, L. (1932). The Sokol Movement in Czechoslovakia. The Slavonic and East European Review, 11(31), 65-80.

16. Kaimakamis, V., Dallas, G., Stefanidis, P. ve Papadopoulos, G. (2011). The spread of gymnastics in Europe and America by pedagogue-gymnasts during the first half of 19 th century. Science of Gymnastics Journal, 3(1) 49-55.

17. Kozáková, Z. (1994). Sokolské slety 1882-1948. Praha: Orbis.

18. Kragujević, G. (2017). Methodology of the Sokol physical exercises for all times. Physical Education and Sport Through the Centuries, 4(2), 88-99.

19. Lejkova-Koeppl, M. (1968). The Sokol Movement': A tribute to the national revival and culture of the Czechoslovak nation. M. Rechcigl, (Ed.), Czechoslovakia Past and Present / Essays on the arts and sciences içinde (s. 1463-1476). De Gruyter Mouton.

20. Martínková, A., Klír, M. ve Swierczeková, L. (2013). Miroslav Tyrš 1837-1950. Inventáře Archivu tělesné výchovy. Erişim adresi: https://www.nm.cz/cs/file/2c7230e8a00ffff00cb 479770438f6d5/5893/Tyr\%C5\%A1\%20Miroslav.pdf

21. Maxwell, A. (2009).Choosing Slovakia: Slavic Hungary, the Czechoslovak language, and accidental nationalism. London: I. B. Tauris.

22. Nolte, C. (1993). "Every Czech a Sokol!": Feminism and nationalism in the Czech Sokol Movement. Austrian History Yearbook, 24, 79-100. 
23. Nolte, C. E. (2002a). “Every Czech a Sokol!” The progressive era in the Sokol. The Sokol in the Czech lands to 1914 içinde. London: Palgrave Macmillan.

24. Nolte, C. E. (2002b). Miroslav Tyrš and his world. The Sokol in the Czech Lands to 1914 içinde. London: Palgrave Macmillan.

25. Nolte, C. E. (2009). Our brothers across the ocean: The Czech Sokol in America to 1914. The International Journal of the History of Sport, 26, 1963-1982.

26. Nolte, C. R. (1996). Choosing Czech identity in nineteenth-century Prague: The case of Jindřich Fügner. Nationalities Papers, 24(1), 51-62.

27. Pavlin, T. (2008). Slovensko sokolstvo je samo po kroju in imenu podobno češkemu ... Troha. M. Šorn ve B. Balkovec. (Ed.), Evropski vplivi na slovensko družbo içinde (s. 155-159). Ljubljana: ZZDS.

28. Pavlin, T. (2013). The duty of a Sokol is to yet again step into the national front line (Sokol Movement in Slovenia - 150th Annıversary of Južni Sokol). Science of Gymnastics Journal, 3(5), 5-18.

29. Pavlin, T. (2018). Historical overview of gymnastics and (school) physical education in Slovenia. Science of Gymnastics Journal, 10(1), 81-90.

30. Pavlin, T. ve Čustonja, Z. (2018). Sokol: Between making nation and state. Kinesiology, 50(2), 260-268.

31. Pavlin, T. ve Žvan, M. (2014). Herald of new, healthier mode of life (Academization of physical education and formation of the Faculty of Sport). Kinanthropologica, 50(2), 21-29.

32. Polidoro, J. R. (2000). Sport and physical activity in the modern world. Boston, USA: Allyn and Bacon.

33. Preclik, V. (2019). Masaryk a legie. Karviná: Paris.

34. Prica, V. P. (2013). Influence of ideology on the architecture of sokol houses in the Kingdom Of Yugoslavia. Zbornik Matice Srpske Za Likovne Umetnosti, 41, 143-151.

35. Riordan, J. ve Krüger, A. (1999). The international politics of sport in the twentieth century. London: Routledge.

36. Riordan, J. ve Krüger, A. (2003). European cultures in sport: Examining the nations and regions. Bristol, UK: Intellect.

37. Sak, R. (2012). Miroslav Tyrš: Sokol, myslitel, výtvarný kritik. Praha: Vyšehrad.

38. Savić, Z., Zdravkovic, D. ve Siljak, V. (2014). The "Sokol" movement as a model of intercultural cooperation. Historicky Casopis, 62(4), 679-693.

39. Sekot, A. (2010). Sport and physical activity in Czech Republic. Sport Science Review, 19(1-2), 159176.

40. Sesum, V. ve Milosevic, Z. (2014). Sokol movement in Vojvodına from 1869 to 1945. Physical Education and Sport Through the Centuries, 1(2), 4-18.

41. Sirotkina, I. (2017) Natsional'nye modeli fizicheskogo vospitaniya i sokol'skaya gimnastika v Rossii. The Russian Sociological Review, 16(2), 320-339.

42. Škegro, D. ve Čustonja, Z. (2015). History of physical education in Croatia. P. D. Pavlovic, N. Zivanovic, B. Antala. ve K. M. Pantelic Babic, (Ed.), History of Physical Education in Europe I içinde (s. 39-57). University of Pristina, Faculty of Sport and Physical Education in Leposavic.

43. Štěrbová, G. ve Vlček, P. (2015). A brief history of the development of physical Education in Czech Lands. P. D. Pavlovic, N. Zivanovic, B. Antala. ve K. M. Pantelic Babic, (Ed.), History of Physical Education in Europe I içinde (s. 58-71). University of Pristina, Faculty of Sport and Physical Education in Leposavic.

44. Şinoforoğlu. T. (2020). Selim Sırrı Tarcan ve İsveç Jimnastiği. Ankara: Spor Yayınevi ve Kitabevi.

45. [Tarcan], Selim Sırrı (1928). Türk ocakları ve bedeni terbiye. Türk Yurdu, 1/21(4/198), 38-40.

46. [Tarcan], Selim Sırrı (1930). Başka milletlerde spor: Sokollar. Muhit, 2(24), 433-435.

47. Troch, P. (2019). Interwar Yugoslav state-building and the changing social position of the Sokol gymnastics movement. European Review of History: Revue Européenne D'histoire, 26(1), 60-83.

48. Türel, O. (2015). “Uzun” XIX. yüzyılda Orta Avrupa: Bir Habsburg üçlemesi. İstanbul: Yordam Kitap. 
49. Viktorovich, K. V. (2014). The meeting (Slet) of the Czech Sokol Movement in Brno on June 27 28, 1914. Всемирная История, 94(4), 61-70.

50. Vít, M. ve Reguli, Z. (2015). The role of combatives teaching in physical education. Brno: Faculty of Sports Studies, Masaryk University.

51. Vukašinović, V., Mijatović, S., Šiljak, V., Veličković, S., Strelić, D. ve Stevanović, M. (2016). Contribution of Dr. Laza Popović to the development of Serbian and Yugoslav Sokol movement. Vojnosanitetski Pregled, 73(10), 976-979.

52. Waic, M. (2013). Tělovýchova a sport ve službách české národní emancipace. Praha: Karolinum.

53. Zec, D. (2015). The Sokol movement from Yugoslav origins to King Aleksandar's 1930 All-Sokol Rally in Belgrade. East Central Europe, 42(1), 48-69.

54. Zmuda-Palka, M. ve Siwek, M. (2018). Large scale Gymnastic Festivals (Pan-Sokol Slets): The greatest social movement on Polish territory prior to the First World War. The International Journal of the History of Sport, 35(14), 1428-1443. 
Bu sayfa boş bırakıımıştır. 